\title{
Higher Education Institutions as a Transformation Platform under the Sustainable Development Goals Framework
}

\author{
Inés López López ${ }^{1}$, Marcos Bote ${ }^{1}$, Longinos Marín Rives ${ }^{1}$ \\ and Alicia Rubio Bañón ${ }^{1}$
}

\begin{abstract}
Previous research has highlighted the critical role of Higher Education Institutions (HEI) in promoting sustainability. In this vein, HEI, as a driving force of change, should actively participate in the diffusion and dissemination of the Sustainable Development Goals (SDGs) proposed by the United Nations. Thus, HEI must boost SDGs attainment both internally, through research, teaching, arts, and curricular programs, and externally, by providing a platform where different stakeholders such as firms, NGOs, public administrations, professional associations, trade unions... meet and create strategic alliances. A Spanish university has implemented a two-year project where different actors (faculties, students, NGO's, private companies, public administration, professional associations, trade unions,...) are already working jointly in the pursuit of the SDGs. The aim of this project is two-fold. First, we intend to increase awareness of the SDGs among members of the university and, second, we want to exert an effective social impact by promoting intervention activities proposed by NGO's and schools. Lectures, art exhibitions, workshops, volunteering programs,... enable tackling the SDGs in focus from different perspectives and contribute to their achievement. As a result, we expect more favorable attitudes towards the SDGs and a behavioral change among university members and citizens in general.
\end{abstract}

Keywords: Sustainable Development Goals, Higher Education Institutions, multi-stakeholders partnership, transformation platform

\section{Introduction}

Maybe the most challenging issue of our time lies in finding the path to sustain the world's resources, while providing well-being for a demanding population (Boeve-de Pauw et al., 2015). The planet is at risk and humans need to assume their role and try to keep a balance between those two opposing forces. The alarming facts speak for themselves. According to the United Nations, 836 million people live in extreme poverty, over one third of the world's food is wasted, one in four health care facilities lacks basic water provision, oceans are warming, global temperature is increasing, more than 1 billion people do not have access to fresh water, different forms of inequalities exist across the globe,... To deal with this situation, the concept of sustainable development has emerged and many nations have agreed upon addressing it through international treaties and declarations. For example, the Millenium Goals and the 17 Sustainable Development Goals proposed by the United Nations represent well known examples.

Sustainable development is not an easy task. Otherwise, several goals could have been met already and that is not actually the case. Lots of actors such as nations, citizens, or public institutions, among others, are expected to make a contribution to their 
achievement. High Education Institutions (HEI, hereafter) are not an exception. On the contrary, their key role in shaping the future generations professional profiles makes it especially salient for them to build the bridge between their students and sustainable development (Aleixo et al., 2018).

As recognized by Koehn and Uitto (2014), for decades, the critical role of HEI in sustainability have been recognized in a wide array of declarations, charters and initiatives that have been ratified by them to prove their commitment towards sustainable development (Talloires Declaration, 1990; Halifax Declaration, 1991; Swansea Declaration, 1993; Global Higher Education for Sustainability Parnership, 2000; Graz Declaration on Committing Universities to Sustainable Development, 2005; Rio +20 Higher Education Sustainability Initiative, 2012). However, despite the positive attitude and heightened awareness, the results have fallen short on reaching a remarkable impact. In this context, a Spanish university has implemented a two-year project where different actors (more than 20 faculties, 30,000 students and 60 NGO's, among others) are already working jointly in the pursuit of the Sustainable Development Goals (SDGs) proposed by the United Nations in 2015 under the term 2030 Agenda. The aim of this project is two-fold. First, we intend to increase awareness of the SDGs among members of the university and, second, we want to exert an effective social impact by promoting intervention activities proposed by NGO's and schools.

The structure of the paper is as follows. First, we briefly revised the literature about the role of HEI in promoting sustainability. Then, the project is presented and the procedure is described. Finally, the main outcomes, the difficulties we faced and the implications are discussed.

\section{Theoretical Background}

As stated above, there is little doubt universities play a significant role in the development of society. Actually, their decisions should emerge from the firm conviction that it is their duty to positively contribute to social change. Sustainable development is probably one of the key areas where they could and should actively work (Lidstone et al. 2015; Ramos et al. 2015). In other words, nowadays the world faces important threats and HEI must have a say in minimizing their impact.

Consistently, previous research has stressed the critical role of HEI in promoting sustainability (Holm et al. 2015; Lozano et al. 2015), especially if we take into account Olson and Gerikke's (2016) results showing that students' sustainability consciousness dips in adolescence. This finding means that students commonly enter university without a real concern about economic, social and environmental issues. Consequently, those students become a very important target for sustainable development initiatives carried out at HEI. In that vein, from 1972 until 2010, many international declarations highlighted the Education for Sustainable Development in HEI (Grindsted and Holm, 2012). Later, the United Nations Conference on Sustainable Development, known as Rio+20, reached the conclusion that sustainability had to be promoted beyond the UN Decade of Education for Sustainable Development (UN, 2012). What is more, some authors warn that many universities are becoming more market-oriented so that consumer-centric policies and increased industry involvement in curricula are gaining more attention than sustainability 
pedagogy (Slocum et al. 2019). This trend led authors such as Lozano et al. (2013) and Larrán-Jorge et al. (2015) to call for integral implementation of sustainability, meaning that such sustainability should become apparent in most, if not all, university activities as a mechanism to ensure education for sustainable development.

From a theoretical point of view, this recommendation seems obvious and out of question; however, reality proves that effective implementation is not an easy task. Although many efforts to incorporate sustainable development into HEI have been made (Cortese, 2003; Lidstone et al. 2015), they tended to be compartmentalized, that is to say, they focused on specific domains instead of adopting a holistic view. Similarly, Alonso-Almeida et al. (2015) indicated that the diffusion of sustainability reporting is still at an early stage in universities, and no massive diffusion is expected in the near future, despite the growing concern. Moreover, as Evangelinos and Jones (2009) claimed, factors like managers' reluctance and lack of functional targets and knowledge also represent obstacles to incorporate sustainable initiatives successfully. But despite the difficulties, HEI must promote sustainability, as the positive outcomes have been proved. In that regard, Boeve-de Pauw et al. (2015) demonstrated that education for sustainable development impacts on student outcomes in terms of their sustainability consciousness.

\section{The 2030 Agenda as the Blueprint for the Project}

In 2015, all the countries of the United Nations adopted the so-called 2030 Agenda, an ambitious plan comprised of 17 Sustainable Development Goals, which represent the global challenges the world faces nowadays. They are a call for action for all countries, either rich or poor, and their achievement could depict a better future for all. The underlying purpose is to build economic growth and tackling a wide range of social issues (education, health, hunger or inequalities, among others), while addressing environmental concerns. Different actors such as nations, public institutions, private companies, citizens... are encouraged to play a role in their pursuit. As stated above, higher education institutions are not an exception. On the contrary, they are expected to lead social change and transform societies (Barth and Rieckmann, 2012). Thus, the 2030 Agenda has been used in this project because of the university's strong belief that it is its duty to educate students in the values represented by the SDGs and to encourage them to take action in their pursuit.

\subsection{Project goals}

As stated previously, the aim of the project is two-fold: to increase awareness of the SDGs among members of the university and to transform society by carrying out activities that have a real impact on citizens. In this line, the university will serve as a platform for different stakeholders to work jointly, as will be explained later.

\subsection{Procedure: building partnerships}

The purpose of bringing together different stakeholders, taking advantage of the fact that a wide variety of agents could easily feel comfortable when collaborating with a Higher Education Institution, led us to follow a multi-stage process where stakeholders adhered to the project at different points in time. 
Thus, the first step was to meet the Deans of all the Faculties and Schools of the university, so they could choose which SDGs they would participate on, based on their areas of expertise and the problems addressed by the SDGs. A monthly calendar was developed afterwards.

The second step was to gather more than fifty NGOs and associations and invite them to collaborate in the project. Similar to what schools did, they were asked to choose the SDGs more closely related to their courses of action.

Once the schools and NGOs were assigned to the goals, a program capturing all the activities proposed by the participating agents was settled. The basis for such a monthly program was set in a preparatory meeting where all the participants suggest initiatives that, afterwards, were integrated in the schedule. Along the month, around 50-60 activities related to the focused SDG are developed. They include: lectures, workshops, art exhibitions, field trips, volunteering programs, fairs... These take place all over the university, but mainly in the hosting schools.

Third, a meeting with the students' council took place. Although the scope of the project is wide, meaning that any member of the university as well as any person from civil society can attend the different sessions, we must acknowledge that students are the most important stakeholder for the project. Therefore, it was mandatory to ask them about their interests and preferences with regard to the activities and rewards.

Fourth, the project was presented to the regional authorities. They believed that the project has the potential to both make people aware of the challenges we all face and exert a powerful impact on society. Consequently, they joined the project as a sponsor. In the same vein, a bank and a local water and sewer system company offered financial support to the project, becoming official sponsors too.

With all these agents on board, the project's opening ceremony took place in January and the activities started in February. From that moment on, other actors have come into play, as the media announce and cover different events. As a result, trade unions, more sNGOs, professional associations and private companies have contacted us with the aim of joining the project. This trend confirmed the university role as a partnership platform where a very diverse array of agents works together to make a better world, providing different and non-mutually exclusive perspectives into the 2030 Agenda implementation (see Figure 1). This is in line with Leal Filho (2011), who suggested that one of the key aspects of the implementation sustainability in Higher Education related to translating the "added" value of such sustainability to different stakeholders.

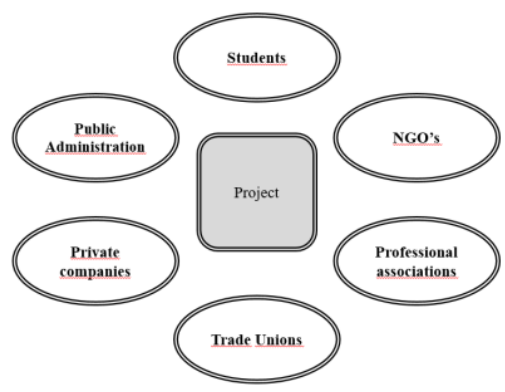

Figure 1. Stakeholders involved in the project 


\subsection{The 2030 Agenda in students' curricula}

Previous research has called for a more comprehensive integration of sustainability into curricula (Larrán-Jorge et al. 2015). If HEI are really committed to the attainment of the SDGs, they should place them at the core of their mission, that is to say, the essence of sustainable development must be introduced into the students' curricula. Being aware of this extent, in the project, we created an interactive space where experts, professors and students are given the opportunity to discuss the way the corresponding SDG could be implemented into their degrees. Definitely, this initiative materializes the belief that the promotion of sustainable development must start with a change in the focus HEI follow to educate those who will lead the world in the future and whose actions will drive the planet's direction.

\section{Outcomes}

The two main goals in this project are progressively being achieved. On the one hand, awareness about the SDGs has increased. On the other hand, we are actually promoting changes. They might be small at this point but they could also open future avenues for a major impact. Activities such as attending a visit to a shelter where people in high social risk are accommodated and trained to return to society or providing food for those in need or learning how to convert traditional food waste into something edible or being confronted with the barriers some vulnerable groups encounter regarding access to education could encourage students to actively work in pursuit of the SDGs both from their personal and professional lives.

Probably, the most objective way of assessing the success of the project is by tracking the number of participants attending the different activities (lectures, workshops, trips,...). Thus, we registered the number of attendants to the activities carried out during the first four months and the figure is close to 4.000 students.

Another mechanism to measure the project's outcomes relates to social media reach. In that regard, 97 videos were recorded during the first months and the number of visualizations was above 3,700 . Similarly, the project website received 6,500 visits and the number of followers in the different social networking sites increased at a steady pace. Finally, with respect to media coverage, according to our tracking, almost 80 pieces of news were published in different newspapers and websites during the first period.

But, of course, as it always happens with a highly innovative experience, this project did not evolve without some difficulties. At first, mobilizing students turned out to be a tough task not because of their lack of interest but mostly due to the wide array of options they are offered on the part of their professors, faculties, university in general as well as external agents. We realized that this situation could lead to some level of information overload with, in turn, resulted in lower engagement. Thus, in an attempt to overcome this drawback, we asked for the collaboration of the Deans and their ViceDeans. The rationale is that they are constantly in touch with the students at their schools and, consequently, they have the ability to recommend them what activities to attend. We expect that, as they become more familiar with the project, their intrinsic motivations to engage in a sustainable behavior and learn more about it would be enough for them to attend. 


\section{Implications}

The most valuable contribution of the project probably refers to the provision of a multi-stakeholder framework to make the Sustainable Development a reality. We believe that this project is easily transferable to other Higher Education Institutions, as its cross-cultural applicability originates at the innate global scope of the SDGs. The platform we propose might serve as a base model to implement sustainability in a holistic way. As stated previously, to the best of our knowledge, this is the first attempt to gather different stakeholders under a common umbrella to work for the 17 SDGs proposed by the United Nations. The requirement of conducting the implementation based on holistic and system's thinking and action is, therefore, met (Ferrer-Balas et al. 2009) and involves medium and long term plans for the institutionalization of sustainability, as suggested by Lozano et al. (2015).

University professors are well aware of the need for bringing sustainable development into teaching activities as it may prove instrumental for the students' professional future. In that regard, the basis for the incorporation of the SDGs into curricula has been placed in this project, as it offers an opportunity to discuss the alternatives to deal with sustainability at both course and degree levels, in line with Holm et al. (2015) and Slocum et al (2019) call for action. These sessions are expected to train professors to, subsequently, inspire critical thinking among students regarding topics aligned with the SDGs.

Some authors suggest that the only way to assess effectiveness in the implementation of sustainable development is to monitor and quantify the activities (Lozano et al. 2015). In that regard, different indicators about attendants, stakeholders, visits to the website, followers, media coverage are recorded. Therefore, the project design enables measurement. In the near future, new tools could be incorporated to evaluate more accurately whether the project is shaping students' attitudes and behavior. The scale developed by Biasutti and Frate (2017), where four dimensions of attitude toward sustainable development -environment, economy, society and education- are distinguished, and the Michalos et al.'s (2015) Student Sustainable Development Survey could be used.

Moreover, the psychology of sustainability suggests that sustainability does not only tackle ecological and socio-economic concerns but it has also the potential to improve individuals' quality of life (Di Fabio, 2017). Therefore, organizations and their staff can benefit from embedding sustainable development in their strategies and policies. HEI are not an exception so we expect members of the university to feel proud of, engaged in and perceive the positive outcomes of the project.

\section{References}

Aleixo, A.M., Leal, S. \& Azeiteiro, U.M. (2018). Conceptualization of sustainable higher education institutions, roles, barriers, and challenges for sustainability: An exploratory study in Portugal, Journal of Cleaner Production, 172, 1664-1673.

Alonso-Almeida, M.M., Marimon, F., Casani, F. \& Rodríguez-Pomeda, J. (2015). Diffusion of sustainability reporting in universities: current situation and future perspectives. Journal of Cleaner Production, $106,144-154$. 
Barth, M. \& Rieckmann, M. (2012). Academic staff development as a catalyst for curriculum change towards education for sustainable development: an output perspective, Journal of Cleaner Production, 26, 28-36.

Biasutti, M. \& Frate, S. (2017). A validity and reliability study of the Attitudes toward Sustainable Development scale, Environmental Education Research, 23(2), 214-230. DOI: 10.1080/13504622.2016.1146660

Boeve-de PauwB., Gericke N., Olsson D. \& Berglund, T (2015). The Effectiveness of Education for Sustainable Development, Sustainability, 7, 15693-15717. DOI:10.3390/su71115693

Cortese, A.D. (2003). The critical role of higher education in creating sustainable future. Planning for Higher Education, 15-22.

Di Fabio, A. (2017). The psychology of sustainability and sustainable development for well-being in organizations. Frontiers in Psychology, 8, 1-7.

Evangelinos, K-I. \& Jones, N. (2009). An analysis of social capital and environmental management of higher education institutions. International Journal of Sustainability in Higher Education, 10(3), 334-342.

Ferrer-Balas, D., Bruno, J., Mingo, M. \& De Sans R. (2004). Advances in education transformation towards sustainable development at the Technical University of Catalonia, Barcelona. International Journal of Sustainability in Higher Education, 5(3), 251-266.

Grindsted, T.S. \& Holm, T. (2012). Thematic development of declarations on sustainability in higher education. Environmental Economics, 3 (1), 32-40.

Holm, T., Sammalisto, K., Grindsted, T.S. \& Vuorisalo, T. (2015). Process framework for identifying sustainability aspects in university curricula and integrating education for sustainable development, Journal of Cleaner Production, 106, 164-174.

Koehn, P., \& Uitto, J. (2014). Evaluating sustainability education: Lessons from international development experience. Higher Education, 67(5), 621-635.

Larrán Jorge, M., Herrera Madueño, J. Calzado Cejas, M.Y. \& Andrades Peña, F.J. (2015). An approach to the implementation of sustainability practices in Spanish universities. Journal of Cleaner Production, 106, 34-44.

Leal Filho, W. (2011). Abuot the role of universities and their contribution to sustainable development. Higher Education Policy, 24, 427-438.

Lidstone, L., Wright, T., \& Sherren, K. (2015). An Analysis of Canadian STARS-rated Higher Education Sustainability Policies. Environment, Development and Sustainability, 17(2), 259-278.

Lozano, R-. Ceulemans, K., Alonso-Almeida, M., Huisingh, D., Lozano, F.J., Waas, T., Lambrechts, W., Lukman, R. and Hugé, J. (2015). A review of commitment and implementation of sustainable development in higher education: results from a worldwide survey, Journal of Cleaner Production, 108, 1-18.

Michalos, A.C., Kahlke, P.M., Rempel, K. Lounatvuori, A., MacDiarmid, A., Creech, H. \& Buckler, C. (2015). Social Indicators Research, 123, 303-336. https://doi.org/10.1007/s11205-014-0752-1

Olsson, D. \& Gericke, N. (2016). The adolescent dip in students' sustainability consciousness Implications for education for sustainable development, The Journal of Environmental Education, 47(1), 35-51.

Ramos, T.B., Caeiro, S., van Hoof, B., Lozano, R., Huisingh, D. \& Ceulemans, K. (2015). Experiences from the implementation of sustainable development in higher education institutions: Environmental Management for Sustainable Universities, Journal of Cleaner Production, 106, 3-10.

Slocum, S., Dimitrov, D.Y. \& Webb, K. (2019). The impact of neoliberalism on higher education tourism programs: Meeting the 2030 sustainable development goals with the next generation, Tourism Management Perspectives, 30, 33-42.

UN (2012). The future we want. http://www.uncsd2012.org/content/documents /727The\%20Future\%20We\%20Want\%2019\%20June\%201230pm.pdf 